\title{
Correction to: Core curriculum illustration: pediatric viral parotitis
}

\section{Barbara Pawley $^{1} \cdot$ Sibi Rajendran $^{1} \cdot$ Ramya Kondaveeti $^{1}$}

Published online: 29 June 2019

(C) American Society of Emergency Radiology 2019

\section{Correction to: Emerg Radiol (2019) 26:361-363 \\ https://doi.org/10.1007/s10140-017-1521-7}

The published version of this article unfortunately contained a mistake in the Abstract section. The ASER Core Curriculum and Recommendations for Study website incorrectly captured as http://www.aseronline.org/curriculum/toc.htm. The ASER Core Curriculum website can be found here: https://www.aser. org/core-curriculum/.

Pulisher's note Springer Nature remains neutral with regard to jurisdictional claims in published maps and institutional affiliations

The online version of the original article can be found at https://oi.org/ 10.1007/s10140-017-1521-7

Barbara Pawley

bkpa223@uky.edu

1 Department of Radiology, University of Kentucky, 800 Rose Street, Room HX 313E, Lexington, KY 40356-0293, USA 